藤田行代志 ${ }^{1}$, 関塚雅之 ${ }^{1}$, 中村智德 ${ }^{12}$, 本德理恵 ${ }^{1}$, 阿部正樹 ${ }^{1}$, 中村克德 ${ }^{2}$, 荒木拓也 ${ }^{2}$, 飯塚惠子 ${ }^{1}$, 山本康次郎 ${ }^{* 12}$

群馬大学医学部附属病院薬斉部 ${ }^{1}$, 群馬大学大学院医学系研究科臨床薬理学 ${ }^{2}$

\title{
Evaluation of Drug Transfer Device for Use in Preparation of Anticancer Drugs by Unskilled Persons
}

\author{
Yukiyoshi Fujita ${ }^{1}$, Masayuki Sekizuka ${ }^{1}$, Tomonori Nakamura ${ }^{1,2}$, Rie Hontoku ${ }^{1}$, \\ Tadashige Abe ${ }^{1}$, Katsunori Nakamura², Takuya Araki², \\ Keiko lizuka ${ }^{1}$ and Koujirou Yamamoto ${ }^{* 1,2}$ \\ Department of Pharmacy, Gunma University Hospital ${ }^{1}$, \\ Department of Clinical Pharmacology, Gunma University Graduate School of Medicine ${ }^{2}$
}

$\left[\begin{array}{l}\text { Received February 25, } 2010 \\ \text { Accepted November 17, } 2010\end{array}\right]$

With the increasing demand for the preparation of sterile admixtures of anticancer drugs by pharmacists, it is important that their preparation can be done efficiently and safely, even by unskilled persons. In 2008, a drug transfer device which aids the preparation of anticancer drugs (Chemo Mini-Spike ${ }^{\circledR}$; CMS) was launched in Japan.

A Ithough this transfer device is said to be advantageous in that it makes drug preparation more rapid and reduces the risk of contamination and incidence of coring during preparation, there is no evidence to support this. Therefore, in this study, we compared CMS with a method using an 18 gauge injection needle (IN) regarding preparation time and incidence of spillage and coring when used by 15 unskilled pharmacists. The total preparation time using CMS was significantly shorter than that using IN (150.0 13.8 vs. 175.3 $23.7 \mathrm{~s} ; p<0.001)$. In particular, the time for aspiration of the solution from the vial was 2.5 times shorter for CMS $(37.2 \pm 6.0$ vs. 90.5 $\pm 15.7 \mathrm{~s} ; p<0.001)$. Though the incidence of spillage for CMS was less than half of that for IN, this was not significant. There was only 1 case of coring among 45 preparations and this was with the IN method. Our results suggest that CMS is a more efficient method for admixture preparation by unskilled pharmacists.

Key words — drug transfer device, anticancer drug, exposure, Chemo Mini-Spike ${ }^{\circledR}$, preparation time

\begin{abstract}
緒言
がん治療においては, 年々新しい治療法が開発され， がん化学療法は目覚しい発展をとげている. 兴の結果， 患者の生存期間が延長することにより，治療を継続する がん患者も増大し，抗がん薬の注射剂混合調製業務も増 え続けている.特に，患者の quality of life(QOL)向上へ の配慮や抗がん薬および支持療法の進歩とともに，2002 年に新設された外来化学療法加算(300点)が, 2006 年に は 400 点，2008年には 500 点，さらに 2010 年には 550 点(外来化学療法加算 1)へと引き上げられる等, 医療経
\end{abstract}

済的な状況の変化もあり，外来における化学療法はます ます増加している ${ }^{12}$. このため, より効率的な業務を行 うことが重要である゙ 用される抗がん薬の多くは細胞障害性抗がん薬であり， 細胞毒性，変異原性および発がん性等を有する．弚のた め，これらの抗がん薬を取り扱う医療従事者に対する被 曝の問題が注目され, 米国労働安全衛生研究所(NIOSH ; National Institute for Occupational Safety and Health)から 「危険な医薬品を使用したり，炎の光ばで作業をしたり すると, 皮膚発疹, 不妊症, 流産, 先天性異常, および 場合によっては白血病光の他のがんを発症する恐れがあ る」ことが警告されている4).このことは，抗がん薬混 
医療薬学 Jpn. J. Pharm. Health Care Sci.

合調製を安全に行う手技が求められることを示してい る.NIOSH の警告では，安全な抗がん薬混合調製を行 うために，個人保護具や安全キャビネットに加え，閉鎖 式の薬物混合器具の併用を推奨している. 閉鎖式薬物混 合器具としては PhaSea ${ }^{\circledR}$ (カルメル・ファルマ・ジャパ ン(株))がよく知られており，弚の利用により作業者およ び周囲への污染が抑えられたとの報告が国内外から多く なされている ${ }^{5-9)}$. わが国でも PhaSeal ${ }^{\circledR} の$ 導入が広がり つつあるが, コストの問題があり，抗がん薬を扱うす心゙ ての施設で利用されているわけではない .

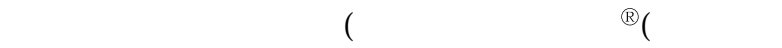
ラウンェースクラップ(株))，以下，CMS と略す)がわが 国で発売された(図 1) . 海外ではスウェーデン, スペイ ン, ポルトガル, ドイツ等, ヨーロッパを中心に普及し ており，米国でも使用されている する一般的な調製法(IN 法)と比べ，CMSを使用した場 合(CMS 法)には，(1)エア吸入口があるため，ポンピング 作業やエア針による空気の置換を行わずにバイアル内の 薬液を吸引することができ, 調製時間および作業量を軽 減できる，(2)エアフィルターにより揮発した抗がん斉か らの曝露を軽減できる，(3)先端開放型のIN と異なり， 針穴が横に位置するプラスチック針であるため，ゴム栓 のコアリングのリスクを軽減できる，等の利点があげら れている.しかしながら，これらの特徵を客観的に評価 したデータはない，注射薬混合操作に熟達した操作者で あれば，いずれの方法でも効率よく正確な作業を行うこ とができると考えられるが, 未熟達者では調製器具の性 能により，作業効率や混合調製された注射薬の品質に大 きく差が現れる可能性がある. 弚こで本研究では，CMS を使用した場合の調製時間およびコアリングやスピル (液垂れ)発生のリスクを評価するため，注射薬混合調製 に不慣れな作業者を対象に，調製時間，スピルおよびコ
アリングの発生頻度について IN を使用した場合と比較 した .なお，今回の試験では，薬液としてフルオレセイ ン水溶液を用いたため, スピルの有無によって薬液污染 のリスク軽減を評価し，揮発性抗がん斉の曝露について は評価を行わなかった .

方法

1. 器具および試料

液体調製器具として CMS(ビー・ブラウンェースク ラップ(株))および18ゲージx 1 1/2インチ針(テルモ (株))を用いた、注射筒には $50 \mathrm{~mL}$ 容量のルアーロック 式シリンジ(テルモ(株))を使用した . バイアル製剂は市 販のフルオレセイン溶液(フルオレサイト ${ }^{\circledR}$, 日本アルコ ン(株))を蒸留水で 500 倍に希釈したもの $50 \mathrm{~mL}$ を，あ らかじめ $50 \mathrm{~mL}$ 用バイアル内に注入し, 液状用ブチル ゴム(大)およびフリップキャップ(いずれも日電理化硝子 (株))をハンドクリッパー(手動式巻締機)にて密栓したも のを用いた . 作成したフルオレセイン入りバイアルは , 外側に付着したフルオレセインを除去するため，水で周 囲を洗浄してから試験に用いた . 輸液バッグは，予備容 量を確保し過度の内圧上昇を避けるために生理食塩水の バッグ製剤(テルモ生食 $500 \mathrm{~mL}$ ，テルモ(株))から内容物 を $50 \mathrm{~mL}$ 除去したものを使用した .

\section{2. 被験者}

注射薬混合調製に不慣れな作業者 15 名(男性 7 名，女 性 8名.22-27歳)に対し, 試験の目的および内容を説 明し, 同意を得て被験者とした。被験者らは薬学系の大 学あるいは大学院の実習において, 注射薬混合作業を経 験したことがあるものの, 客観的臨床能力試験(OSCE) の受験や注射薬混合業務に従事した経験はなかった .
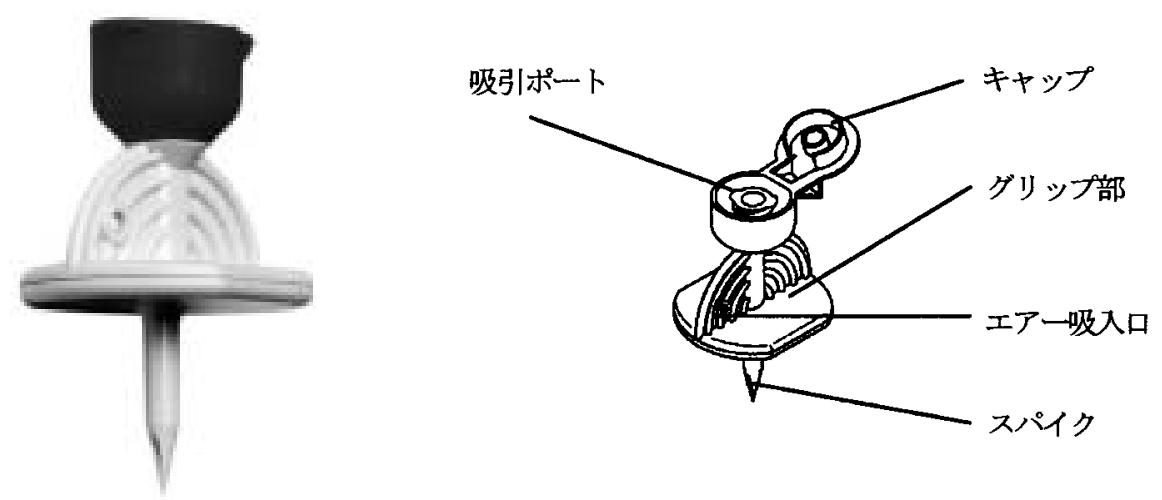

図 1 . ケモミニスパイク ${ }^{\circledR}$ 外観と構造 . キャップの付いたルアーロック式の接 続部とプラスチック製の針とで構成され, 内部は通気用および薬液用の流 路に分かれた構造になっている. 通気用流路には $0.4 \mathrm{~m}$ \%エアフィルター 付きエア吸入口があり, 薬液用の流路には $5 \mu \mathrm{m}$ の異物除去フィルターが 内装されている .フィルターはポリエーテルスルフォン製であり，抗がん 薬の溶解に用いられるエタノール含有溶媒に対しても耐性である. 


\section{3. 比較試験}

15名の被験者を Group A(男性 3名，女性 4名)および Group B(男性 4名, 女性 4名)に分け，試験の直前に CMSおよびIN を用いた調製方法および試験内容を口頭 および実演により説明した後，光れ光れの調製器具を用 いて $50 \mathrm{~mL}$ 用バイアルから液体を吸引し，光れをバッ グ製剂に注入する手技を 1 回ずつ練習させた．被験者は ガウン(Chemo Safety ${ }^{\circledR}$, Ludlow Company)および二重の 手袋(内側：ニトリル製検査検診用グローブ(Sterling ${ }^{\circledR}$, Kimberly-Clark)，外側：パウダーフリーラテックス製手 術用手袋(Protegrity ${ }^{\circledR}$ ，Cardinal Health)を装着した . 安全 キャビネット 2 台を用い，1台あたり原則 2 名の被験者 が並んで操作を行った.Group A はIN 法に続いて CMS 法, Group B は逆の順で光れ光れの調製器具を使用し， 安全キャビネット内に敷いた A 2 サイズの紙の上で注射 薬混合作業を行った．各被験者には一人ずつ監査者が付 き，操作を確認した．監査者には，薬剂師業務経験 2 年 以上で, 日常的に注射薬の混合調製に携わっている者が 担当した .

注射薬混合作業として，光れ光れの調製器具を用いて $50 \mathrm{~mL}$ 用バイアルから $0.2 \%$ フルオレセインをシリンジ に $45 \mathrm{~mL}$ 吸引し，生理食塩水のバッグ製剂に注入した . この操作を 3 回繰り返す樣子をビデオカメラで撮影し， 操作手順ごとの所要時間を光れ光れ測定し，3回の平均 を兴の被験者の操作時間とした . なお，未熟達者では対 応が困難と考えられるトラブルが発生したために被験者 以外の者が手伝った場合では，㫕の回を除外し，残りの 2 回の平均を被験者の操作時間とした . 操作手順は，

手順 1 注射薬調製器具を包装から取り出し, バイアル 内の液体をシリンジに吸引する準備が終了するまで

手順 2 シリンジ内の空気泡抜きを行いながら , バイア ル内の液体 $45 \mathrm{~mL}$ を吸引終了するまで

手順 3 監査者により液体吸引量の確認を受け, 生理食 塩水のバッグ製剂にIN を刺入するまで

手順 4 シリンジ内の液体全量をバッグ製剂に注入し， リキャップするまで

の4項目に分けて測定した ${ }^{111}$.

各注射薬調製器具による具体的な操作手順は以下の通 りである .

A. CMS 法

手順 1 CMS 包装から取り出してバイアルに刺し込 み, シリンジをCMSに取り付けるまで

手順 2 シリンジ内の空気泡抜きを行いながら，バイア ル内の液体 $45 \mathrm{~mL}$ を吸引終了するまで

手順 3 監査者により液体吸引量の確認を受け，CMS から付け替えた IN を生理食塩水のバッグ製刘に刺入す るまで

手順 4 シリンジ内の液体全量をバッグ製剂に注入し， リキャップするまで
B. IN 法

手順 1 IN を包装から取り出してシリンジに装着した 後, $40 \mathrm{~mL}$ の空気を吸引し , バイアルにIN を刺入する まで

手順 2 空気との置換およびシリンジ内の空気泡抜きを 行いながら，バイアル内の液体 $45 \mathrm{~mL}$ をシリンジに吸 引終了するまで

手順 3 監査者により液体吸引量の確認を受け，INを 生理食塩水のバッグ製剂に刺入するまで

手順 4 シリンジ内の液体全量をバッグ製剂に注入し， リキャップするまで

操作終了直後に安全キャビネット内でA 2 用紙に紫外 光 $(253.7 \mathrm{~nm})$ を照射し, 蛍光を目視することでスピル(液 垂れ)の有無を確認した．また，調製に用いた手袋への 飛散も，外した手袋を広げ，紫外光を照射して確認し た . スピルが生じたタイミングは被験者の操作中に監査 者が確認した上，録画した映像で確認した．さらに，コ アリングの有無は生理食塩水のバッグ製刘の外部を清浄 にし, 白色蛍光灯下の室内(500-1000 Ix)で，肉眼により ゴム破片の浮遊を観察した .

\section{4. 統計解析}

調製時間の結果は平均士 標準偏差で示した . 操作時間 の平均值は, 対応のある 2 群として $\mathrm{t}$ 検定で比較した . スピルの発生頻度はフィッシャーの正確確率検定により 解析した.いずれも有意水準 $5 \%$ 未満を統計的有意差あ りと判断した.

\section{結果}

\section{1. 操作時間}

各調製器具による操作時間を表 1 に示した．手順 4の 吸引した液体をバッグ製剂内に入れる作業以外では， CMS 法と IN 法の操作時間は有意に異なり，手順 2 のバ イアル中の液体を吸引する作業は CMS 法の方が平均 53 秒早く，IN法に比べ倍以上の早さであったが $(p<$ 0.001), 手順 3のシリンジに吸引した液体を生理食塩水

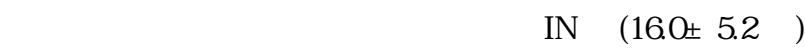
に比べ 2.2 倍であった $(p<0.001)$. 全行程の作業時間は CMS法の方が 25 秒 $(p<0.001)$ 早く，IN 法に比べ $14 \%$ 短かった . なお，CMSからシリンジを外せなくなった ため被験者以外の者が手伝った 2 回，およびIN 法にお いて操作途中にバイアルにフルオレセイン水溶液が垂 れ，監査者の指示による清拭に手間取った 1 回(いずれ も対応に 1 分間以上所要)は, 未熟達者では対応が困難 と考えられるトラブルが発生した例として，操作時間の 算出から除外し , スピルおよびコアリングの有無のみ測 定した。 
表 1 . IN 法およびCMS 法における混合調製の操作時間

\begin{tabular}{lcc}
\hline & IN 法(秒) & CMS 法(秒) \\
\hline 全工程 & $175.3 \pm 23.7$ & $150.0 \pm 13.8^{* * * *}$ \\
手順 1 & $39.3 \pm 7.1$ & $48.8 \pm 6.7^{* * * *}$ \\
手順 2 & $90.5 \pm 15.7$ & $37.2 \pm 6.0^{* * * *}$ \\
手順 3 & $16.0 \pm 5.2$ & $36.0 \pm 5.9^{* * *}$ \\
手順 4 & $29.0 \pm 5.8$ & $27.7 \pm 4.1$ \\
手順 $1+2$ & $129.9 \pm 20.0$ & $85.9 \pm 10.4^{* * * *}$ \\
\hline
\end{tabular}

操作手順は、手順 1 : 注射薬調製器具を包装から取り出し、バイアル内の液体をシリン ジに吸引する準備が終了するまで、手順 2 : バイアル内の夜体 $45 \mathrm{~mL}$ を゙リンジに吸引 終了するまで、手順 3 : 監查者により液体吸引量の確認孛受けた後、生理食塩水のバ ッグ製剤に IN 刺入するまで、手順 4:シリンジ内の液体全量をバッグ製剤に注入し、 リキャップするまで、とした。 $\mathrm{n}=15 。 * * *: p<0,001$

\section{2. スピルの発生頻度}

CMS 法とIN 法による調製の安全性を比較するため， 操作中に液垂れを起こした被験者数を比較した．IN 法 (15名中 7 名)では, CMS 法(15名中 3名)に比べ2倍以 上の被験者にスピルが認められたが(表 2)，統計学的な 有意差は認められなかった $(p=0.245)$.また，操作に用 いた手袋への飛散は全例で認められなかった .

\section{3. コアリングの発生頻度}

IN 法では 45 例中 1例において生理食塩水のバッグ製 剂内に，浮遊したゴム片が認められた．CMS 法ではコ アリングは認められなかった .

\section{考察}

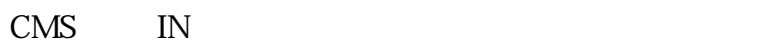
より差が生じると考えられる項目ごとに分けて検討し た．IN 法ではバイアルから液体を吸引する際, 吸引し た液体と空気を置換し，バイアル内が過度な陰圧になら
ないようにしながら調製しなくてはならない，乥れに対 し，CMS法は液体を吸引してバイアル内が陰圧になる とフィルターを通じて清浄な空気がバイアル内に流入す るため, 空気との置換作業(ポンピング)が不要であり， 簡便かつ速やかにバイアル内の液体を吸引することが可 能であると考えられる .これらの特徵により，バイアル 中の液体を吸引する過程(手順 2)においては，CMSを用 いた時の操作時間はIN 法に比べて半分以下であった . 一方, シリンジに吸引した液体を輸液製剂に注入する 際，IN 法では炎のまま針を刺し入れれば良いが，CMS 法ではCMSを輸液バッグに通常は用いないため，IN に 付け替えなければならず，この過程において CMS 法で は操作手順が増え，多くの時間を要した(16.0 $5.2 \mathrm{vs.}$ 36.0土 5.9秒； $p<0.001)$. ただし，IN を用いてバイアル 内の溶液を吸引する時間と，CMSから IN に付け替えて 生食に針を刺し入れるまでの時間では，吸引時間の方が 操作時間全体に占める割合が大きい，光のため，全工程 の作業時間では CMS 法の方がIN 法より平均 25 秒早 かった .このことから , バイアルから液体を吸引し, 輸

表 2 ．IN 法およびCMS 法におけるスピルの発生頻度

\begin{tabular}{lcc} 
& スピルあり(人) & スピルなし人) \\
\hline $\mathrm{IN}$ 法 & 7 & 8 \\
$\mathrm{CMS}$ 法 & 3 & 12 \\
\hline$p=0.245$ (フイッシャーの正確確率検定) &
\end{tabular}


液製剂に注入するという，一般的な注射薬混合作業にお いて，CMS法の方がIN 法より迅速に作業できることが 示唆された。また，薬液を吸引するだけで輸液製剂に注 入しない作業においては，CMSは特に迅速な操作が可 能であると考えられる．例えば，抗がん薬を必要量だけ シリンジに分注する場合においては，時間的な有用性が 大きいと考えられた。なお，CMSからシリンジを外せ なくなったため被験者以外の者が手伝った例では，締め 過ぎにより接続部分が壤れてしまった．CMS とシリン ジの接続部分はネジ式になっているため，必要以上に強 く締め過ぎないことが大切である .

日常の注射薬混合業務は, 主に薬液をバイアルから吸 引した後, 輸液バッグに注入するという作業である.す なわち，CMSにより薬液を吸引した後，INに付け替え て操作するため, この一連の操作全体でCMSがスピル の発生頻度軽減に寄与するか評価する必要がある . 本研 究の結果では, CMS 法では, IN 法に比べスピルの発生 か認められた被験者は半分以下であったものの，有意差 は認められなかった(表 $2, p=0.245)$.より安全にCMS を利用するため，CMSからシリンジを外した後にどの ように操作を行えば良いかは今後の課題である．なお， CMS はバイアルに装着して用いるため，CMSの針先か らのスピルで作業環境が污染されることはない．すなわ ち，INへの付け替え操作が不要となる，抗がん薬をシ リンジに分注するだけの操作においては，CMS を用い ることで薬液污染リスクの低い操作が可能になると考え られる．また，今回用いた注射針は $18 \mathrm{G}$ のRB(regular bevel)針であった .一般に，RB 針より SB(short bevel)針 の方が液垂れしにくいと考えられているため ${ }^{122}$ ，SB 針 を用いることでスピル発生を軽減できる可能性がある．

さらに，コアリングの有無について検討したところ， IN を使用した群では，45例中 1 例にコアリングが認め られたが，CMS を使用した群では，コアリングは認め られなかった，先端開放型のIN と異なり，CMS は針穴 が横に位置するプラスチック針であるため, コアリング が発生し難い構造となっている．ただし，今回の検討で は，INでもコアリングの発生頻度が少なかったため， CMSでコアリングのリスクを軽減できる可能性につい ては，より例数を増やした検討が必要と考えられた。

今回の試験は，混合作業に不慣れな者を被験者として 行った . 通常，抗がん薬の混合調製業務には，熟練した 薬斉師が携わることが望ましいと考えられる．しかし， 病院によっては人手不足により，日常業務において，ま れにしか注射薬混合調製を行わない職種(看護師，医師 等)や新人薬剂師等, 注射薬混合調製に不慣れな者が業 務に携わらざるを得ないケースもある．弚のような状況 では, 抗がん薬の調製をする際にINを用いるより CMS を用いた場合，スピルの発生を増加させることなく，迅 速な調製が可能であることが示唆された．また，コスト 面を考えると，18ゲージx 1 1/2インチ針は 1本あたり
8.7円，CMS は 1本あたり 450 円と大きな差がある . こ のように，CMSはIN に比べコスト面で大きな違いがあ るため, 光の導入については費用対効果を十分に考える 必要がある . 例えば，コスト差と今回示された迅速性・ 安全性を比較して，抗がん薬をシリンジに分注する作業 に限定して利用する等，有用な利用方法を考えなければ ならない，一方，閉鎖式の薬物混合器具としてわが国で も利用が広がりつつある PhaSeal ${ }^{\circledR}$ は, アダプタ 546 円/ 個，インジェクタールアーロック 1029 円/本，プロテク タ 1155 円/本となっている ${ }^{12)}$. 1バイアルに対し 1本使 用するプロテクタだけでも，CMSの2 倍以上の価格で あり，PhaSeal ${ }^{\circledR}$ の代用としてCMS を用いる場合にはコ ストを抑えられる・ただし，CMSは「エアフィルター により揮発した抗がん㶡からの曝露を軽減できる」とさ れているものの，弚の主張の根拠となるデータは見あた らない．CMS は閉鎖式ではないため ${ }^{13)}$, シクロフォス ファミド等の揮発性の抗がん薬の安全な調製には検証の 余地があると考えられる ${ }^{14)}$. また，CMS と同じくポン ピング作業が不要なデバイスとしては, バルーンにより 吸引時のバイアル内陰圧化を防ぐ Genie ${ }^{\circledR}(($ 株)パルメ ディカル)およびケモセープ(テルモ(株))が知られてい る.Genie ${ }^{\circledR}$ は , バイアル内のバルーンが膨らむことによ りポンピングなしで液体の吸引が可能である .1本あた り 880 円であり，CMSに比べ高価であるが，PhaSeal ${ }^{\circledR}$ に比べると安価である .なお, より安全な混合調製のた め, Genie ${ }^{\circledR}$ は, $\operatorname{Spiros}^{\circledR}(595$ 円/本，(株)パルメディカル) との併用が勧められている.ケモセーフ 月に発売され，0.4u m のフィルターによりバイアル内を 等圧化できる一方，完全閉鎖式ではない点は CMS と同 樣である . ケモセーフアダプターは定価が 480 円/個で あり，コストもCMS とほぼ同等である。なお，これら の製品は薬斉師による安全キャビネット内での混合調製 のみならず，患者への投与までを閉鎖系にすることで， 看護師，患者を含めた被曝の軽減を目的としているた め, 専用の輸液システムとの併用が基本である .

IN と比較した際，コスト以外のCMSの欠点として， 残液量の多さがあげられる．CMSおよびIN のデバイス 内の残液量は，弚れ約 $0.45 \mathrm{~mL}$ および 0.14-0.15 mL と3倍異なる ${ }^{1215)}$. また CMSは, シリンジ目盛りの微 量の調節にはやや不向きといわれている ${ }^{15)}$.これらの理 由から，CMS は少量の薬液の採取には不向きであり， 大量の薬液を採取する際に利用することか望ましいと考 えられる。

CMSのようなディスペンシングピンは，欧米では従 来から注射薬の混合に利用されている ${ }^{1510)}$. この背景の 1つには, 日本と欧米における注射薬の容量の違いがあ ると考えられる.例えば米国にはドキソルビシン $(200$ $\mathrm{mg} / 100 \mathrm{~mL})$ やフルオロウラシル $(5 \mathrm{~g} / 100 \mathrm{~mL})$ 等の大容量 規格の注射薬が存在し，1本の注射薬バイアルから複数 の患者の薬液を分取することが可能である(牧野好倫 
ら，日本と米国における注射用抗がん剂規格の比較調 査, 第 15 回日本医療薬学会年会講演要旨集, p 239). CMS は 1バイアルにつき1つ使用するため，わが国の ように小さな規格のバイアルが中心の状況では，1人の 患者のために複数のCMS を利用しなければならず，コ ストの問題が大きくなる . わが国でも大容量規格の注射 薬か増えた場合には，CMSのような調製器具が利用し やすくなるであろう .

今回の試験の結果より，混合作業に不慣れな者におい ては，一般的な調製法であるINよりCMSを用いた方 が，抗がん薬の調製をする際にスピルを増加させること なく，迅速な調製が可能であることが示唆された．ただ し, 薬液をバイアルから吸引した後, 輸液バッグに薬液 を注入するという通常の注射薬混合業務では，CMSを 用いる場合にもINへの付け替えが必要であり，操作時 間の延長，およびスピルを生じるリスクにつながるた め，十分な注意が必要である．ただし，抗がん薬をシリ ンジに分注するだけの作業においては，これらの問題点 を回避できると考えられた .

謝辞 今回の比較試験の実施に関して，監查者としてご協 カいただいた，薬剤部の上出晴香，君島礼子，小島史織，塚 本純子および南亚由美の各諸氏に深謝致します．

\section{引用文献}

1)“がん専門薬剤師を目指すための抗がん薬業務ハンド ブック，第1版”，国立がんセンター薬剤部編，じほう， 東京, 2006, pp. 24-39.

2) 大江裕一郎,“実例から学ぶ安全で有効な外来がん化学 療法の実践, 第 1 版”, 西條長宏編, 先端医学社, 東京, 2007, pp. 10-14.

3）堤一貴, 葉田昌生, 大光正男, 田鶴谷惠子, 野瀬育弘, 鶴田美恵子，三嶋基弘，森田桂子，タキソテール注射 液調製時における効率化の検討，医療薬学，35, 431-435 (2008).

4) National Institute for Occupational Safety and Health, NIOSH A lert", Preventing Occupational Exposures to Antineoplastic and Other Hazardous Drugs in Health Care Settings", DHHS (NIOSH) Publication Number 2004-165, Cincinnati, OH, 2004, pp. 1-50.

5) C. Wick, M.H. Slawson, J.A. Jorgenson, L.S. Tyler, Using a closed-system protective device to reduce personnel exposure to antineoplastic agents, Am. J. Health. Syst. Pharm., 60 , 2314-2320 (2003).
6) B.R. Harrison, B.G. Peters, M.R. Bing, Comparison of surface contamination with cyclophosphamide and fluorouracil using a closed-system drug transfer device versus standard preparation techniques, Am J. Health Syst. Pharm., 63, 1736-1744 (2006).

7) J. Yoshida, G. Tei, C. Mochizuki, Y. Masu, S. Koda, S. Kumagai, Use of a closed system device to reduce occupa tional contamination and exposure to antineoplastic drugs in the hospital work environment, Ann. Occup. Hyg., 53, 153160 (2009).

8) 西垣玲奈, 紺野英里, 杉安美紀, 米村雅人, 大塚知信, 渡邊協孝, 軍司剛宏, 戶塚ゆ加里, 若林敬二, 遠藤一司, 山本弘史，抗がん薬による被曝防止を目的とした閉鎖式 混合調製器具の有用性の検討, 日本病院薬斉師会雑誌, 46 , 113-117 (2010).

9) J. Siderov, S. Kirsa, R. McLauchlan, Reducing workplace cytotoxic surface contamination using a closed-system drug transfer device, J. Oncol. Pharm. Pract., 16, 19-25 (2010).

10) A. Georgiadi, E. Ramme, C. Wretman, S. Eksborg, How to create acceptable working conditions for hospital pharmacy staff when preparing cytotoxic drugs, Eur. J. Hosp. Pharm., 3 , 40-42 (2004).

11）宮松洋信，坂本真澄，東加奈子，石井文雄，前彰，佐藤 京子，小浦千勢，河野佳代，齋藤薰，阿部満子，明石貴 雄，抗がん剂用安全取扱器具 PhaSeal ${ }^{\circledR}$ system の操作性 の評価，医療薬学，32，1211-1221 (2006).

12）日本病院薬斉師会監修“”抗悪性腫瘍斉の院内取扱い指 針抗がん薬調製マニュアル”，北田光一，加藤裕久，濱 敏弘, 中山季昭, 杉浦伸一編, 第 2版, じほう, 東京, 2009 , pp. 274-277.

13) J.A. Jorgenson, S.M. Spivey, C. A u, D. Canann, H. Ritter, B. Smith, Contamination Comparison of Transfer Devices Intended for Handling Hazardous Drugs, Hosp. Pharm., 43 , 723-727 (2008).

14) T.H. Connor, M. Shults, M.P. Fraser, Determination of the vaporization of solutions of mutagenic antineoplastic agents at 23 and 37 degrees $C$ using a desiccator technique, Mutat. Res., 10 , 85-92 (2000).

15) “安全な薬斉投与のための医療材料の選び方・使い方 , 第1版”，杉浦伸一，橋田亨，中西弘和編，じほう，東 京 , 2010, p. 59.

16) M.A. Gravenstein, J.C. Lydon, K. Uttech, Mini-spike Dis pensing Pin-An Efficient Way to Prepare Dantrolene, Anesthesiology, 66 , 254 (1987).

17) G.S. Ogawa, K. Norris, Dispensing-pin problems, Am. J. Hosp. Pharm., 42 , 1042-1045 (1985). 